\title{
Chemical composition and light absorption of carbonaceous aerosols emitted from crop residue burning: influence of combustion efficiency
}

\author{
Yujue Wang ${ }^{1}$, Min $\mathrm{Hu}^{1,2,4}$, Nan $\mathrm{Xu}^{1}$, Yanhong Qin ${ }^{1}$, Zhijun Wu ${ }^{1,2}$, Liwu Zeng ${ }^{3}$, Xiaofeng Huang ${ }^{3}$, and Lingyan $\mathrm{He}^{3}$ \\ ${ }^{1}$ State Key Joint Laboratory of Environmental Simulation and Pollution Control, College of Environmental Sciences and \\ Engineering, Peking University, Beijing 100871, China \\ ${ }^{2}$ Collaborative Innovation Center of Atmospheric Environment and Equipment Technology, Nanjing University of \\ Information Science \& Technology, Nanjing, China \\ ${ }^{3}$ Key Laboratory for Urban Habitat Environmental Science and Technology, School of Environment and Energy, \\ Peking University Shenzhen Graduate School, Shenzhen, China \\ ${ }^{4}$ Beijing Innovation Center for Engineering Sciences and Advanced Technology, Peking University, Beijing 100871, China
}

Correspondence: Min Hu (minhu@pku.edu.cn)

Received: 6 July 2020 - Discussion started: 28 July 2020

Revised: 30 September 2020 - Accepted: 10 October 2020 - Published: 16 November 2020

\begin{abstract}
Biomass burning is one of the major sources of carbonaceous aerosols, which affects air quality, the radiation budget and human health. Field straw residue burning is a widespread type of biomass burning in Asia, while its emissions are poorly understood compared with wood burning emissions. In this study, lab-controlled straw (wheat and corn) burning experiments were designed to investigate the emission factors and light absorption properties of different biomass burning organic aerosol (BBOA) fractions, including water-soluble organic carbon (WSOC), humiclike substances (HULIS) and water-insoluble organic carbon (WISOC). The influences of biofuel moisture content and combustion efficiency on emissions are comprehensively discussed. The emission factors of $\mathrm{PM}_{2.5}$, organic carbon (OC) and elemental carbon (EC) were $9.3 \pm 3.4,4.6 \pm 1.9$ and $0.21 \pm 0.07 \mathrm{~g} \mathrm{~kg}^{-1}$ for corn burning and $8.7 \pm 5.0,3.9 \pm 2.8$ and $0.22 \pm 0.05 \mathrm{~g} \mathrm{~kg}^{-1}$ for wheat burning, generally lower than wood or forest burning emissions. Though the mass contribution of WISOC to OC (32\%-43\%) was lower than WSOC, the light absorption contribution of WISOC (57\%$84 \%$ at $300-400 \mathrm{~nm}$ ) surpassed WSOC due to the higher mass absorption efficiency (MAE) of WISOC. The results suggested that BBOA light absorption would be largely underestimated if only the water-soluble fractions were considered. However, the light absorption of WSOC in the near-UV
\end{abstract}

range, occupying $39 \%-43 \%$ of the total extracted OC absorption at $300 \mathrm{~nm}$, cannot be negligible due to the sharper increase of absorption towards shorter wavelengths compared with WISOC. HULIS were the major light absorption contributors to WSOC, due to the higher MAE of HULIS than other high-polarity WSOC components. The emission levels and light absorption of BBOA were largely influenced by the burning conditions, indicated by modified combustion efficiency (MCE) calculated by measured $\mathrm{CO}$ and $\mathrm{CO}_{2}$ in this study. The emission factors of $\mathrm{PM}_{2.5}$, OC, WSOC, HULIS and organic acids were enhanced under lower MCE conditions or during higher moisture straw burning experiments. Light absorption coefficients of BBOA at $365 \mathrm{~nm}$ were also higher under lower MCE conditions, which was mainly due to the elevated mass emission factors. Our results suggested that the influence of varied combustion efficiency on particle emissions could surpass the differences caused by different types of biofuels. Thus, the burning efficiency or conditions should be taken into consideration when estimating the influence of biomass burning. In addition, we observed that the ratios of $\mathrm{K}^{+} / \mathrm{OC}$ and $\mathrm{Cl}^{-} / \mathrm{OC}$ increased under higher MCE conditions due to the enhancement of potassium and chlorine released under higher fire temperatures during flaming combustion. This indicates that the potassium ion, as a commonly used biomass burning tracer, may lead to 
estimation uncertainty if the burning conditions are not considered.

\section{Introduction}

Biomass burning emissions, as a major primary source of carbonaceous aerosols, have significant effects on air quality, human health and the regional or global radiation budget (Bond, 2004; Chen et al., 2017a; Reid et al., 2005; Saleh et al., 2015). Biomass burning could contribute onethird of the black carbon (BC) budget and two-thirds of the primary organic aerosol budget on the global scale (Bond, 2004; Bond et al., 2013). In recent years, biomass burning organic aerosols (BBOA) also attracted much attention due to their substantial contribution to light-absorbing organic aerosols, known as brown carbon (BrC) (Andreae and $\mathrm{Ge}$ lencsér, 2006; Laskin et al., 2015; Lin et al., 2016; Saleh et al., 2014; Washenfelder et al., 2015; Yan et al., 2018). Emission factors (EFs) of BrC ranged from 1.0 to $1.4 \mathrm{~g} \mathrm{~kg}^{-1}$ biomass, comparable to those of $\mathrm{BC}$ (Aurell and Gullett, 2013). The majority of $\mathrm{BrC}$ aerosol mass was associated with biomass burning emissions in the rural southeast United States (Washenfelder et al., 2015). Regional radiative forcing effects of $\mathrm{BrC}$ could be comparable to those of $\mathrm{BC}$ over major areas dominated by biomass burning and biofuel combustion, such as South and East Asia (Feng et al., 2013).

Emission factors, chemical compositions and light absorption properties of biomass burning aerosols could be obviously influenced by different types of biomass, biofuel structures, moisture contents and especially varied burning conditions (Chen and Bond, 2010; Holder et al., 2016; Reisen et al., 2018). The emissions of particulate organics could span several orders of magnitude depending on different burning conditions (Chen et al., 2017a; Jen et al., 2019). In general, higher levels of particulate matter (PM) and organic aerosols were emitted during less efficient biomass burning, due to prolonged incomplete or smoldering combustion (Holder et al., 2016; Jen et al., 2019; Reisen et al., 2018). Open biomass burning, especially smoldering combustion, dominates the organic carbon (OC) emissions in many regions of the world on an annual-average basis (Bond, 2004). The light absorption of biomass burning aerosols is also largely dependent on the combustion conditions (Cheng et al., 2016a; Liu et al., 2014; Pokhrel et al., 2016; Saleh et al., 2014). The contribution of $\mathrm{BrC}$ to aerosol light absorption at near-UV wavelength was reported to be higher for more smoldering combustion compared with more flaming combustion (Holder et al., 2016). The reported variation trends of BBOA absorption properties as a function of combustion conditions, however, are not consistent among different studies. High variability in reported emission factors and optical properties of BBOA from different burning conditions complicates their treatment in climate models (Liu et al., 2014; Saleh et al., 2014) and indicates the importance of further investigations on biomass burning emissions, especially the influence of burning conditions.

Unlike the well-understood BC, the light-absorbing OC or $\mathrm{BrC}$ comprises a wide range of poorly characterized organic compounds, which exhibit highly variable chemical and light absorption properties (Andreae and Gelencsér, 2006; Laskin et al., 2015; Lin et al., 2016; Saleh et al., 2014; Washenfelder et al., 2015; Yan et al., 2018). Previous studies have suggested that methanol-extracted $\mathrm{BrC}$ was usually more light-absorbing than water extracts for BBOA or ambient aerosols (Chen and Bond, 2010; Liu et al., 2013). More than $92 \%$ of the light-absorbing OC emitted from solid fuel pyrolysis could be extracted by methanol, compared with $73 \%$ for water-extracted compounds (Chen and Bond, 2010). Alkaline- or methanol-extracted OC fractions were also observed with higher mass absorption efficiency (MAE) at $365 \mathrm{~nm}$ than water-soluble organic carbon (WSOC) for residential coal combustion ( $\mathrm{Li}$ et al., 2018). Only considering the water-soluble $\mathrm{BrC}$ would result in underestimation of BrC absorption and radiative forcing (Cheng et al., 2016b, 2017). Different light absorption properties of organic fractions could be attributed to the varied chemical compositions and structures (Chen et al., 2016a, b, 2017b). However, few studies have been conducted to gain a comprehensive understanding of the influence of combustion conditions on the chemical composition and light absorption of different BBOA fractions from agricultural residue burning.

Field open burning of agriculture waste or crop residues is a widespread type of biomass burning in Asia (IARI, 2012; Bond, 2004; Streets et al., 2003). Open crop residue burning during the harvest season results in severely adverse impacts on regional air quality and human health (Chen et al., 2017a; Li et al., 2014; Lin and Yu, 2011; Streets et al., 2003; Zhang et al., 2010). The PM emission factors from agricultural waste burning range from 1.7 to $17.8 \mathrm{~g} \mathrm{~kg}^{-1}$ (Bond, 2004). Source apportionment results showed that $\sim 50 \%$ of carbonaceous aerosols in Beijing were associated with biomass burning, with crop residue combustion being a major source (Cheng et al., 2013). Straw residue burning could contribute as high as $51 \%$ of PM and $76 \%$ of OC during harvest seasons in the agriculture regions in China ( $\mathrm{Li}$ et al., 2014). Considering the large contribution of straw residue burning, the chemical compositions and light absorption properties of BBOA in Asia may differ from other regions whose major type of biomass burning is wood burning. However, the understanding of field straw residue burning emissions is still limited. A better characterization of the emission levels and optical properties of straw burning aerosols is required to quantify their effects on air quality and regional radiation forcing in agriculture areas (Hungershoefer et al., 2008). Laboratory simulation experiments have been suggested as a good way to study biomass burning emissions due to their advantage in quantifying emission factors and controlling combustion conditions within well-defined limits. In 
this study, a series of lab burning experiments were designed to systematically investigate the emission factors, chemical compositions and light absorption properties of both watersoluble and water-insoluble carbonaceous aerosols emitted from straw residue burning. The influence of biofuel moisture contents, burning conditions and combustion efficiency on the BBOA emission levels and light absorption properties is comprehensively discussed.

\section{Methods}

\subsection{Simulation and sampling of biomass burning aerosols}

Lab-controlled burning experiments were conducted in the Laboratory of Biomass Burning Simulation at Peking University Shenzhen Graduate School. The simulation system was designed and optimized on the basis of the one used in $\mathrm{He}$ et al. (2010), which included a combustion system, dilution system, sampling system and data acquisition system (Fig. S1 in the Supplement). During each experiment, about 1-2 kg biomass fuel was ignited on the combustion pan. The emitted smoke was collected by the hood above the fire and diluted by zero air $\left(21 \mathrm{~mol} \% \mathrm{O}_{2}\right.$ and $79 \mathrm{~mol}_{\%} \mathrm{~N}_{2}$ ) before being collected on filters or monitored by online instruments. Smoke aerosols were collected on both Teflon (Whatman Inc.) and quartz fiber (Whatman Inc.) filters, using a $\mathrm{PM}_{2.5}$ cutoff with a sampling flow rate of $16.7 \mathrm{~L} \mathrm{~min}^{-1}$. During each burning experiment, $\mathrm{CO}$ and $\mathrm{CO}_{2}$ were measured continuously by $\mathrm{CO}$ and $\mathrm{CO}_{2}$ analyzers (Thermo Scientific Inc., Bremen, Germany). The burning efficiency, calculated based on the online $\mathrm{CO}$ and $\mathrm{CO}_{2}$ data, was monitored continuously during each experiment (Table S1 in the Supplement). The variation of fire temperatures during each experiment was also measured by a sensor above the fire (Fig. S1).

In this study, the burning of corn and wheat, two kinds of primary grain crops in China, was simulated to represent the straw residue burning in China. To investigate the influence of biofuel moisture contents on burning emissions, straw with different levels of moisture contents was burned, including low $(13 \%)$ and high $(18 \%)$ levels for corn burning experiments and low (7\%-9\%), medium (18\%-22\%) and high (27\%-33\%) levels for wheat burning experiments (Table S1). The moisture content was measured by weighing the fuels before and after drying the biofuels in the oven at $105^{\circ} \mathrm{C}$ for $24 \mathrm{~h}$. Straw residues with different moisture contents were prepared by mixing weighed biofuels with weighed pure water in a plastic box and shaking until the water was absorbed. Each experiment condition was repeated three times. All the conducted experiment conditions as well as burning conditions are summarized in Table S1.

\subsection{Isolation of carbonaceous aerosols}

Quartz fiber filters were used to extract different carbonaceous aerosol fractions, including water-insoluble organic carbon (WISOC), WSOC and the carbon component of humic-like substances $\left(\mathrm{HULIS}_{\mathrm{C}}\right)$. The filter samples were firstly extracted twice in an ultrasonic bath using $10 \mathrm{~mL}$ ultrapure water each time, for $30 \mathrm{~min}$ each. The extracts were then combined and filtered with a $0.45 \mu \mathrm{m}$ pore size syringe filter (Gelman Sciences) to obtain the WSOC solutions. After removing the WSOC fraction on filters, the WISOC fractions were then extracted twice in an ultrasonic bath using $5 \mathrm{~mL}$ methanol each time, for $30 \mathrm{~min}$ each. The extracts then were combined and filtered using a $0.25 \mu \mathrm{m}$ syringe filter. The HULIS fraction was isolated from the WSOC solutions via solid phase extraction (SPE), with the majority of lowmolecular-weight organic acids (with relatively higher polarities) and sugars removed from the water solutions. Details about the HULIS extraction procedures were described in our previous paper (Wang et al., 2017). The WSOC fraction that excluded HULIS was high-polarity WSOC (WSOC-h) in this study.

\subsection{Quantification and light absorption measurements of carbonaceous aerosols}

The total OC abundance was analyzed by a thermal/optical carbon analyzer (Sunset Laboratory). The concentrations of water-soluble carbonaceous aerosol fractions, including WSOC and HULIS $_{\mathrm{C}}$, were measured using a total organic carbon (TOC) analyzer (AnalytikJena multi N/C 3100). The WISOC concentrations were obtained by the difference between total OC and WSOC. The light absorption of the extracted solutions (WSOC, HULIS $\mathrm{C}$ and WISOC) was measured by a UV-Vis spectrometer (UV-1780, Shimadzu) over the wavelength range of $300-700 \mathrm{~nm}$. The absorptions of WSOC and WISOC were added up to represent the absorption of the total extracted OC. The absorption coefficients $\left(\mathrm{Abs}_{\lambda}, \mathrm{Mm}^{-1}\right)$ and mass absorption efficiency $\left(\mathrm{MAE}_{\lambda}\right)$ of isolated solutions at a wavelength $\lambda$ were calculated as follows (Cheng et al., 2011, 2016b):

$$
\begin{aligned}
& \operatorname{Abs}_{\lambda}=\left(A_{\lambda}-A_{700}\right) \frac{V_{\text {sol }}}{V_{\text {air }} \times L} \times \ln (10) \\
& \operatorname{MAE}_{\lambda}=\frac{\operatorname{Abs}_{\lambda}}{C},
\end{aligned}
$$

where $A_{\lambda}$ and $A_{700}$ represent the measured absorbance at wavelength $\lambda$ and $700 \mathrm{~nm}$. $A_{\lambda}$ is referenced to the $A_{700}$ to account for systematic baseline drift (Xie et al., 2019; Zhang et al., 2013). $V_{\text {sol }}$ is the volume of extracted solutions, and $V_{\text {air }}$ is the volume of air sampled through the filter punch. The optical path length $(L)$ is $1 \mathrm{~cm}$ in the present experiments. $\ln (10)$ is used to convert from a common logarithm to a natural logarithm. $C$ corresponds to the concentrations of OC, WISOC, WSOC or HULIS $C$ fractions. It is noted that 
the total OC was used to represent the concentration of total extracted OC, which may lead to an underestimation of MAE of WISOC. Previous studies suggested that 92\%-99.7\% of BBOA could be extracted by methanol (Chen and Bond, 2010; Xie et al., 2019); thus the residue OC un-extracted by methanol was relatively small compared with the extracted fraction. The wavelength dependence of light absorption is described using the absorption Ångström exponent (AAE), which is calculated by a linear regression fit of $\log \left(\mathrm{Abs}_{\lambda}\right)$ versus $\log (\lambda)$ in the wavelength range of $300-450 \mathrm{~nm}$.

The radiation effects of different $\mathrm{BrC}$ fractions (WSOC, HULIS and WISOC) relative to elemental carbon (EC, $f$ ) were estimated using a simplified model (Kirillova et al., 2014; Wu et al., 2020):

$$
f=\frac{\int I_{0}(\lambda)\left\{1-e^{-\left(\mathrm{MAE}_{\mathrm{BrC}, 365}\left(\frac{365}{\lambda}\right)^{\mathrm{AAE}} \cdot C_{\mathrm{BrC}} \cdot h_{\mathrm{ABL}}\right)}\right\} \mathrm{d} \lambda}{\int I_{0}(\lambda)\left\{1-e^{-\left(\mathrm{MAE}_{\mathrm{EC}, 870}\left(\frac{870}{\lambda}\right) \cdot C_{\mathrm{EC}} \cdot h_{\mathrm{ABL}}\right)}\right\} \mathrm{d} \lambda},
$$

where $\mathrm{MAE}_{\mathrm{BrC}, 365}$ and $\mathrm{MAE}_{\mathrm{EC}, 870}$ represent the MAE of different $\mathrm{BrC}$ fractions at $365 \mathrm{~nm}$ and MAE of EC at $870 \mathrm{~nm}$. $\mathrm{AAE}$ is the $\mathrm{AAE}$ value of different $\mathrm{BrC}$ fractions obtained in this study, and the $\mathrm{AAE}$ of $\mathrm{EC}$ is set to $1 . C_{\mathrm{BrC}}$ and $C_{\mathrm{EC}}$ are the concentrations of $\mathrm{BrC}$ and $\mathrm{EC}$, and $h_{\mathrm{ABL}}$ is the height of the atmospheric boundary layer $(1000 \mathrm{~m}) . I_{0}(\lambda)$ represents the clear-sky Air Mass 1 Global Horizontal solar irradiance (Levinson et al., 2010).

Water-soluble $\mathrm{K}^{+}$and $\mathrm{Cl}^{-}$and low-molecular-weight organic acids (acetic acid, formic acid, succinic acid, oxalic acid, propionic acid and methanesulfonic acid) were analyzed by an ion chromatograph (DIONEX, ICS2500/ICS2000), following the procedures described in Guo et al. (2010).

\section{Results and discussion}

\subsection{Burning conditions and combustion efficiency}

The burning conditions and combustion efficiency of the simulation experiments, calculated by measured $\mathrm{CO}$ and $\mathrm{CO}_{2}$ concentrations, are shown in Fig. 1 and Table S1. Modified combustion efficiency (MCE), defined as $\Delta \mathrm{CO}_{2} /\left(\Delta \mathrm{CO}_{2}+\right.$ $\triangle \mathrm{CO}$ ), is used to indicate the burning conditions during a fire (Akagi et al., 2011; Andreae and Merlet, 2001). The burning conditions in this study varied for different fires, with the MCE ranging from 0.68 to 0.88 and an average value of 0.77 . The amount and compositions of substances emitted from a given fire are determined to a large extent by the burning conditions or the ratio of flaming to smoldering combustion, which is often expressed as "combustion efficiency". Higher MCE (>0.9) indicates more flaming combustion, and lower MCE indicates more smoldering conditions. A previous study suggested that pure flaming has an
MCE near 0.99, and the MCE of most smoldering combustion is around or lower than 0.8 (Akagi et al., 2011). The burning experiments were generally dominated by smoldering combustion in the present study. Smoldering-dominated conditions, with an expected MCE $<0.9$ or even lower, have been widely observed during the combustion of agricultural residues in the field (IARI, 2012; Wang et al., 2017); thus the results in this study are applicable to field or related model studies.

The biomass fuels with lower moisture contents are generally burned more efficiently, with relatively higher MCE values (Table S1, Fig. S2 in the Supplement), which suggested a higher proportion of flaming combustion during the fire. The MCE of higher moisture biomass burning was generally lower, and prolonged smoldering combustion was observed (Figs. 1 and S2). Previous lab-controlled burning experiments also reported a similar phenomenon that higher fuel moisture lowers the combustion efficiency, shortens the flaming phase and introduces prolonged smoldering combustion (Chen et al., 2010). The relative proportion of flaming versus smoldering phases can vary considerably as a function of fuel moisture. A similar MCE was also observed among wheat burning experiments with different levels of moisture contents (Table S1). This was because the MCE is not only influenced by biofuel moisture contents but also the variations of biofuel structures (e.g. size), burning temperatures or ambient conditions (Chen and Bond, 2010; Lu et al., 2009; Sanchis et al., 2014). We cannot completely exclude the differences of other factors between each parallel experiment, which was the reason for repeating each condition three times in our experiment (Table S1).

Figure 1 displays variations of the monitored parameters $\left(\mathrm{CO}, \mathrm{CO}_{2}, \Delta \mathrm{CO} / \Delta \mathrm{CO}_{2}\right.$ and fire temperature) during two selected burning experiments (low-moisture biomass burning with $\mathrm{MCE}=0.83$ and high-moisture biomass burning with $\mathrm{MCE}=0.68$ ). Different burning conditions dominate during different periods of a fire, and the length of each period varied by experiment (Fig. 1). Actually, flaming and smoldering phases occur simultaneously during a fire, and the proportions of different combustion types vary over time (Akagi et al., 2011; Andreae and Merlet, 2001). For example, the initial period of the low-moisture biomass burning experiment (Fig. 1a) is dominated by flaming, wherein $\mathrm{CO}_{2}$ increased rapidly to the highest level and $\Delta \mathrm{CO} / \Delta \mathrm{CO}_{2}$ ratios were lower (MCE was higher) compared with the smolderingdominated period. The fire temperatures were very high during this initially high-efficiency burning period. During the later period, smoldering dominated the burning conditions. The burning efficiency and fire temperatures decreased during this period, and $\Delta \mathrm{CO} / \Delta \mathrm{CO}_{2}$ ratios were higher than the first period. Previous ground-based and aircraft measurements of wildfire emissions also observed gradually decreased combustion efficiency of a fire over time (Collier et al., 2016). For the high-moisture biomass burning, smoldering combustion dominated the fire types during the whole 


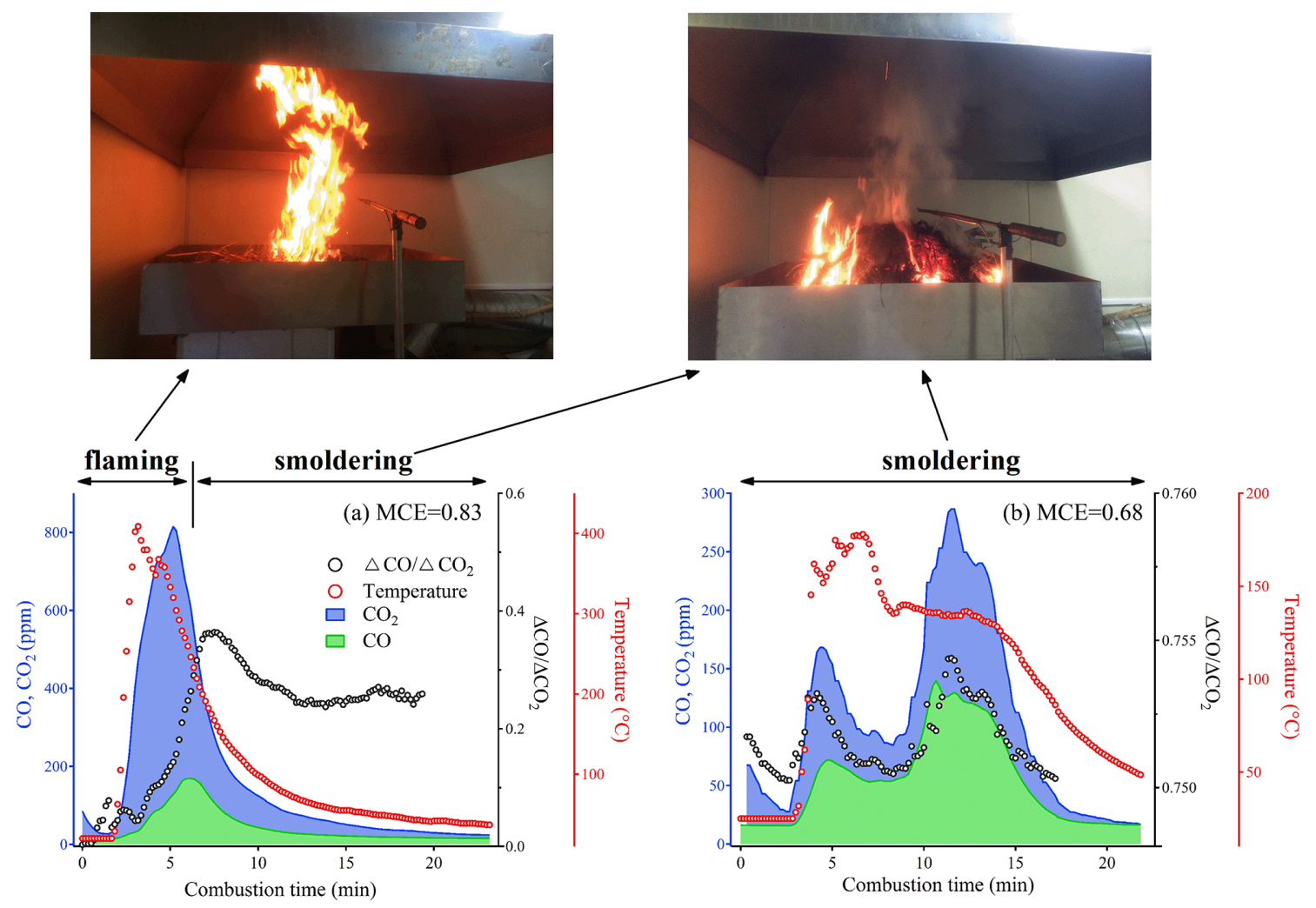

Figure 1. Variations of measured $\mathrm{CO}$ and $\mathrm{CO}_{2}$ concentrations, $\Delta \mathrm{CO} / \Delta \mathrm{CO}_{2}$, fire temperatures and burning conditions during two selected experiments, with an averaged MCE value of (a) 0.83 and (b) 0.68 .

period (Fig. 1b). In higher moisture fuel burns, some energy released from the combustion is first used to dry up the higher moisture of the biofuels; thus the fire temperatures and burning efficiency were lower than those of the low-moisture biomass burning.

\subsection{Emission factors of carbonaceous aerosols}

The average emission factors of $\mathrm{PM}_{2.5}$, $\mathrm{OC}$ and $\mathrm{EC}$ were $9.3 \pm 3.4,4.6 \pm 1.9$ and $0.21 \pm 0.07 \mathrm{~g} \mathrm{~kg}^{-1}$ for corn burning and $8.7 \pm 5.0,3.9 \pm 2.8$ and $0.22 \pm 0.05 \mathrm{~g} \mathrm{~kg}^{-1}$ for wheat burning (Fig. 2). The measured emission factors in this study fall within the range of previous straw burning experiments (4.712.9, 1.2-8.9 and $0.17-1.2 \mathrm{~g} \mathrm{~kg}^{-1}$ for $\mathrm{PM}_{2.5}$, OC and EC, respectively) (Akagi et al., 2011; Hays et al., 2005; Li et al., 2007). The estimated EFs from crop residue burning were generally lower than wood or forest burning emissions (Akagi et al., 2011; Aurell and Gullett, 2013; Jen et al., 2019). However, open crop residue burning in the field could result in severe air pollution during the harvest season, especially in agricultural areas in China and South Asia (IARI, 2012; Li et al., 2014; Streets et al., 2003; Venkataraman et al., 2006). This type of biomass burning cannot be neglected in these regions.

Organic matter $(\mathrm{OM})$, calculated by multiplying $\mathrm{OC}$ by 1.3 (Li et al., 2007), was the dominant component of straw burning aerosols, which accounted for $\sim 64 \%$ and $\sim 55 \%$ of the $\mathrm{PM}_{2.5}$ emitted from corn and wheat burning, respectively (Fig. 2). Around $57 \%$ and $68 \%$ of the OC from corn and wheat burning is water-soluble, and HULIS $_{\mathrm{C}}$ represents $53 \%$ and $46 \%$ of the WSOC. Though the mass contributions of WISOC were lower than WSOC in straw burning aerosols (Fig. 2), the WISOC fractions cannot be neglected, especially when considering the light absorption properties of BBOA (see Sect. 3.4). Previous studies also suggested a large portion of WISOC in ambient aerosols, which are an important contributor of light-absorbing $\mathrm{BrC}$ (Cheng et al., 2016b, 2017).

The average EFs of water-soluble acetic acid, formic acid, succinic acid and oxalic acid were respectively $13.3 \pm 13.9$, $4.1 \pm 3.3,8.8 \pm 10.6$ and $2.2 \pm 1.1 \mathrm{mg} \mathrm{kg}^{-1}$ for corn burning and $13.0 \pm 14.5,4.7 \pm 5.3,9.9 \pm 13.5$ and $3.1 \pm 1.9 \mathrm{mg} \mathrm{kg}^{-1}$ for wheat burning (Fig. 2). Propionic acid and methanesulfonic acid in most samples were below the instrument detection limits in this study, and their emissions were not taken into consideration in the following discussion. The quantified water-soluble low-molecular-weight acids averagely accounted for $0.84 \%(0.16 \%-1.6 \%)$ and $0.88 \%(0.24 \%-$ $1.8 \%$ ) of the water-soluble OM (WSOM) emitted from corn and wheat burning. A previous study has suggested that lowmolecular-weight organic acids represented an important 

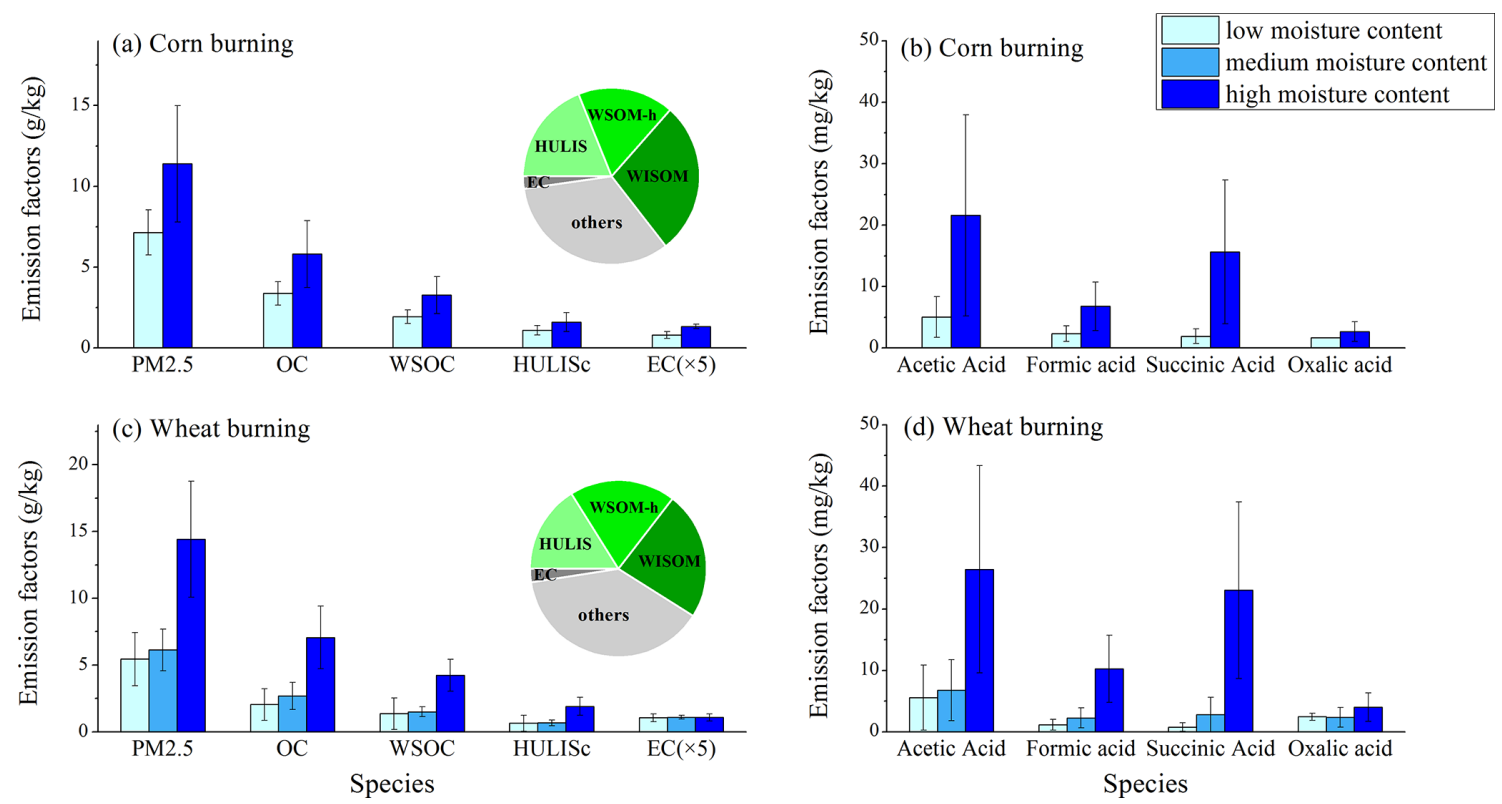

Figure 2. Emission factors of $\mathrm{PM}_{2.5}$, OC, WSOC, HULIS $\mathrm{C}$ and EC from (a) corn burning and (c) wheat burning and emission factors of low-molecular-weight organic acids (acetic acid, formic acid, succinic acid, and oxalic acid) from (b) corn burning and (d) wheat burning. The EC emission factors are represented by $5 \times \mathrm{EC}$ due to the low values. The pie charts in (a) and (c) represent the contribution of major carbonaceous aerosols to $\mathrm{PM}_{2.5}$. The high-polarity WSOM (WSOM-h) is calculated by subtracting HULIS from WSOM. Different moisture content levels correspond to those shown in Table S1.

fraction of WSOC in BBOA, and oxalic acid was a dominant short dicarboxylic (C2-C6) acid (Falkovich et al., 2005). The estimated emission factors of acetic acid and formic acid in this work were lower than those emitted from eucalypt forest fires, which were reported to be 17 and $26 \mathrm{mg} \mathrm{kg}^{-1}$ for flaming combustion and 104 and $94 \mathrm{mg} \mathrm{kg}^{-1}$ for smoldering combustion based on ground-based field measurements (Reisen et al., 2018). The difference could be attributed to different biofuels and burning conditions as well as experimental methods conducted.

Figure 2 compares the emission factors of $\mathrm{PM}_{2.5}$, carbonaceous aerosols and low-molecular-weight organic acids from straw residue burning under different levels of moisture contents. The EFs of fine particles and organic carbonaceous aerosols from high-moisture biomass burning were obviously higher than those from low-moisture biomass burning. Substantial particulate carbonaceous aerosols could be generated from the burning of higher moisture biofuels, which is mainly associated with the prolonged smoldering phases and less efficient combustion (Fig. 1, Table S1). Similar variation trends were also reported in previous biomass burning studies (Chen et al., 2010; Sanchis et al., 2014). Different levels of biofuel moisture contents will actually influence the burning conditions and thus impact the emission levels and compositions of particulate matter.

\subsection{Influence of combustion efficiency on emission factors}

As shown in Fig. 3, the emission factors of $\mathrm{PM}_{2.5}$ and organic carbonaceous components increased with decreasing MCE. Particle emissions were obviously enhanced under less efficient burning conditions. The emission factors of $\mathrm{PM}_{2.5}, \mathrm{OC}$, WSOC and HULIS $_{C}$ from the most smoldering combustion experiment were about 3.4, 4.3, 3.8 and 2.8 times those from the most flaming combustion condition, regardless of the biomass type. Similar to the emission of OC or WSOC, the emission factors of low-molecular-weight organic acids also showed increasing trends with decreasing combustion deficiency (Fig. S3 in the Supplement). These trends are generally in agreement with previous studies (Dhammapala et al., 2006; Holder et al., 2016; Jen et al., 2019; Reisen et al., 2018; Wang et al., 2013). Under the same burning conditions, the emission factors of particles or organic aerosols from corn burning were slightly higher than those from wheat burning (Fig. 3). This was mainly due to the different pyrolysis temperatures and combustion efficiency of different biofuels, which influence the burning processes (Khan et al., 2009; Zanatta et al., 2016). Our results suggested that the influence of varied burning conditions or combustion efficiency on particle emissions could surpass the differences between the two types of straw residue burning measured in this study (Fig. 3). Thus, the burning efficiency or conditions should be 
Low combustion efficiency

(a) $\mathrm{PM}_{2.5}$

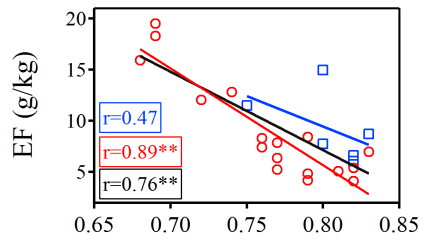

(c) WSOC

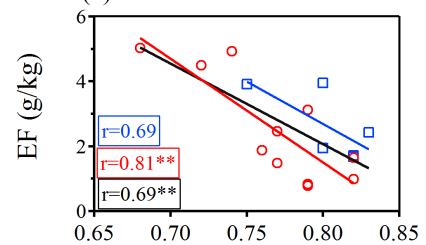

(e) EC

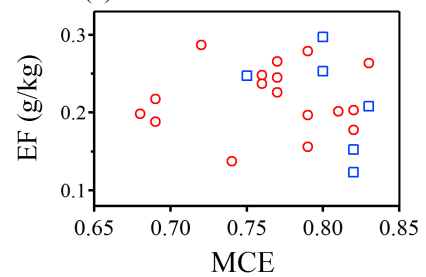

Low combustion efficiency

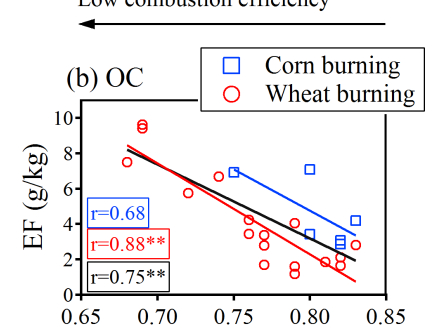

(d) HULIS-C

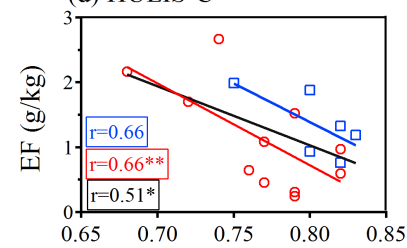

(g) $\mathrm{EC} /(\mathrm{OC}+\mathrm{EC})$

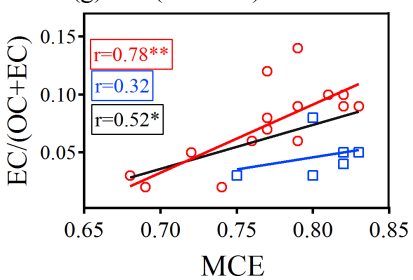

Figure 3. Emission factors of $\mathrm{PM}_{2.5}$, carbonaceous aerosols (OC, WSOC, HULIS $\mathrm{C}_{\mathrm{C}}$ and $\left.\mathrm{EC}\right)$ and $\mathrm{EC} /(\mathrm{OC}+\mathrm{EC})$ ratios as a function of modified combustion efficiency (MCE). Corn and wheat burning emissions are denoted by red and blue colors, respectively. The $r$ values in each panel are the Pearson correlations between emission factors and MCE for corn (blue), wheat (red) and the overall (black) burning experiments. The ${ }^{* *}$ or ${ }^{*}$ following the $r$ value indicates the correlation is significant at the 0.01 level or 0.05 level (two-tailed).

taken into consideration when simulating or estimating the influence of biomass burning emissions in future models.

Different from organic compounds, the emission factors of EC under different combustion efficiency remain relatively consistent (Fig. 3e). Holder et al. (2016) summarized the results from lab and field studies and also found that the black carbon emission factors from different studies are relatively constant, despite the differences in plume dilution or measurement methods (Holder et al., 2016). Some studies, however, reported an increasing trend in EC or BC emission levels with the increasing of combustion efficiency in wildfires or forest burns in the United States (Aurell and Gullett, 2013; Jen et al., 2019). As the conducted experiments were mostly dominated by smoldering combustion $(\mathrm{MCE}=0.68-0.88$ ) in this study, we cannot exclude the possibility that the EC emissions may be higher under flaming-dominated combustion (e.g. MCE > 0.9). Though the EC emission factors did not show obvious variation trends as a function of $\mathrm{MCE}$, a positive correlation between $\mathrm{EC} /(\mathrm{OC}+\mathrm{EC})$ ratios and combustion efficiency was observed (Fig. 3g). Due to the obvious dependence of $\mathrm{EC} / \mathrm{OC}$ or $\mathrm{EC} /(\mathrm{OC}+\mathrm{EC})$ ratios on burning efficiency, these ratios could be employed to indicate differ- ent burning conditions when the emitted $\mathrm{CO}$ and $\mathrm{CO}_{2}$ data are not available, which have been used in previous studies (Xie et al., 2018, 2019).

To further investigate the influence of burning conditions on the chemical compositions of biomass burning aerosols, mass ratios of $\mathrm{WSOC} / \mathrm{OC}, \mathrm{HULIS}_{\mathrm{C}} / \mathrm{OC}, \mathrm{K}^{+} / \mathrm{OC}$ and $\mathrm{Cl}^{-} / \mathrm{OC}$ as a function of burning efficiency are plotted in Fig. 4. The WSOC / OC and HULIS $\mathrm{C} / \mathrm{OC}$ mass ratios ranged from 0.52 to 0.78 and 0.16 to 0.54 among different burning experiments. The HULIS $\mathrm{C} / \mathrm{OC}$ ratios were comparable to those $(0.26-0.44$, with an average of 0.34$)$ reported in field or controlled chamber combustion experiments (Lin et al., 2010). We did not observe obvious variation trends of WSOC / OC or HULIS $\mathrm{C} /$ OC ratios with MCE (Fig. 4), which indicated relative constant BBOA chemical compositions under different combustion conditions. However, the $\mathrm{K}^{+} / \mathrm{OC}$ and $\mathrm{Cl}^{-} / \mathrm{OC}$ ratios showed consistent variation trends under different MCE conditions, which increased from $<0.1$ under the more smoldering condition to $>0.5$ under the more flaming condition for $\mathrm{K}^{+} / \mathrm{OC}$ and from 0.05 to $>0.5$ for $\mathrm{Cl}^{-} / \mathrm{OC}$ (Fig. 4). The highest $\mathrm{K}^{+} / \mathrm{OC}$ (0.64) and $\mathrm{Cl}^{-} / \mathrm{OC}(0.61)$ ratios were observed in a lowmoisture wheat burning experiment with an MCE of 0.79 . This is because the $\mathrm{K}$ and $\mathrm{Cl}$ emissions from combustion are highly affected by fire temperatures and burning conditions. Lab-controlled experiments suggested that the proportions of released potassium and chlorine from the biomass fuels increase with the applied combustion temperatures (Jensen et al., 2000; Knudsen et al., 2004). Much higher fire temperatures were observed for the flaming combustion (with higher MCE) than the smoldering combustion (with lower MCE) (Fig. 1). Though the emission levels of particles or organic aerosols decreased during higher efficiency burning (Fig. 3), elevated proportions of potassium and chlorine were released into smoke during the flaming combustion phase under this condition (Fig. 4b). The two wheat burning experiments (moisture content $=7 \%$ ) with higher $\mathrm{K}^{+} / \mathrm{OC}$ and $\mathrm{Cl}^{-} / \mathrm{OC}$ ratios $(>0.5)$ than others were related to the higher combustion temperatures during the initial flaming periods of the burning experiments (Fig. S4 in the Supplement). The potassium ion is a commonly used tracer to indicate the biomass burning emissions. However, our results revealed that $\mathrm{K}^{+}$cannot correctly indicate the emission levels of biomass burning aerosols under obviously different burning conditions, which may lead to large uncertainty in estimating burning emissions if the combustion conditions are not considered.

\subsection{Light absorption of BBOA}

The light absorption of straw burning organic aerosols decreased sharply from near-UV to visible wavelengths (Fig. 5), indicating their properties as biomass-burninggenerated $\mathrm{BrC}$. The absorption of WISOC, WSOC and HULIS $_{C}$ at $300 \mathrm{~nm}$ was as high as 4.5, 15.2 and 11.2 times 

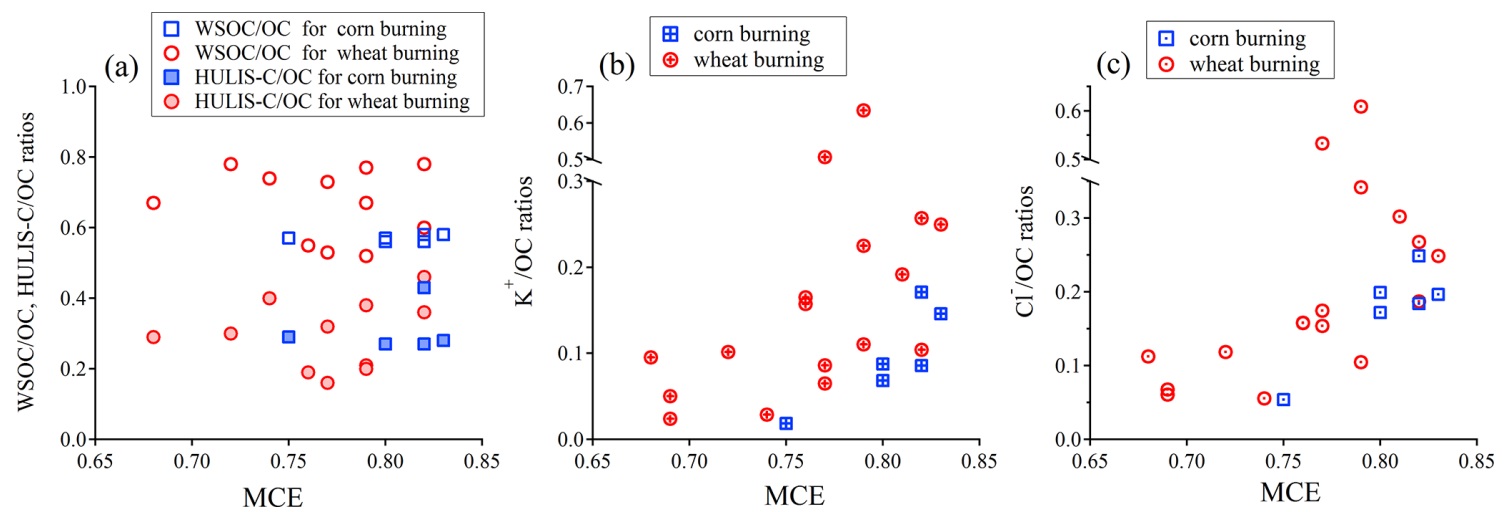

Figure 4. Variations of (a) WSOC / OC and HULIS $\mathrm{C} / \mathrm{OC}$ ratios, (b) $\mathrm{K}^{+} / \mathrm{OC}$ and (c) $\mathrm{Cl}^{-} / \mathrm{OC}$ ratios as a function of modified combustion efficiency (MCE) for corn and wheat burning experiments. Corn and wheat burning emissions are denoted by red and blue colors, respectively.

those at $400 \mathrm{~nm}$ for corn burning emissions and 4.8, 9.2 and 10.6 times those for wheat burning emissions. The wavelength dependence property of BBOA light absorption was described by AAEs derived from the absorption in the range of $300-450 \mathrm{~nm}$. The AAEs of WISOC, WSOC and HULIS $_{\mathrm{C}}$ were respectively $5.8-5.9,8.6-11.3$ and $8.9-10.2$ for corn burning aerosols and 5.7-6.0, 8.1-9.0 and 9.0-10.5 for wheat burning aerosols, and the averaged values are also shown in Fig. 5. The water-soluble BBOA fractions (WSOC and HULIS) showed stronger wavelength dependence than the water-insoluble fractions. The estimated AAE values of straw burning organic aerosols in this study are comparable to those of BBOA (5.3-8.1) and biomass burning-influenced atmospheric aerosols (5.2-9.4) reported in previous studies (Hecobian et al., 2010; Hoffer et al., 2006; Wu et al., 2018, 2019; Xie et al., 2017, 2019; Zhu et al., 2018). The strong light absorption of biomass-burning-generated $\mathrm{BrC}$ in the near-UV range leads to an increase in aerosol light absorption and radiative forcing efficiency (Chakrabarty et al., 2010).

The WISOC was the most important light-absorption fraction among straw burning organic aerosols, which contributed $61 \%-84 \%$ and $57 \%-72 \%$ of the light absorption (at 300-400 nm) by extracted $\mathrm{BrC}$ emitted from corn and wheat burning (Fig. 5). In the wavelength range of $300-400 \mathrm{~nm}$, HULIS $_{\mathrm{C}}$ and other high-polarity WSOC (WSOC-h $=$ WSOC-HULIS ${ }_{\mathrm{C}}$ ) respectively contribute to $16 \%-28 \%$ and $1 \%-10 \%$ of the total BBOA absorption for corn burning and $17 \%-29 \%$ and $12 \%-15 \%$ for wheat burning. Though the mass contribution of WISOC was lower than WSOC (Fig. 2), the light absorption of WISOC surpassed WSOC due to the higher light absorption capability of water-insoluble BBOA, indicated by the higher MAE of WISOC (Fig. 6). Meanwhile, the light absorption of watersoluble BBOA in the near-UV range cannot be neglected due to their sharper increase of absorption towards shorter wavelengths compared with WISOC (Fig. 5). The light absorption contribution of WSOC to extracted $\mathrm{BrC}$ increased substantially from $16 \%-28 \%$ at $400 \mathrm{~nm}$ to $39 \%-43 \%$ at
$300 \mathrm{~nm}$. Among the water-soluble BBOA, HULIS were the major contributors of light absorption, which occupied $74 \%$ and $68 \%$ of the WSOC absorption at $300 \mathrm{~nm}$ for corn and wheat burning emissions, respectively. This was due to the higher light absorption capability of HULIS than other highpolarity WSOC fractions (Fig. 6), though their mass contributions were comparable in straw burning aerosols (Fig. 2).

The light absorption capabilities of different BBOA fractions are compared in Fig. 6. The estimated $\mathrm{MAE}_{365}$ values of straw-burning-generated $\mathrm{BrC}$ in this study are comparable to those reported in previous studies (Fan et al., 2018; Xie et al., 2017). The MAEs of WISOC are higher than water-soluble BBOA (WSOC and HULIS) among the measured wavelength ranges for both corn and wheat burning aerosols. The $\mathrm{MAE}_{300}$ of WISOC was 1.6 and 1.7 times that of WSOC emitted from corn and wheat burning and comparable to that of HULIS (Fig. 6). Due to the slower decrease of WISOC absorption towards visible wavelengths than the water-soluble fractions (Fig. 5), the $\mathrm{MAE}_{365}$ of WISOC was as high as 2.5 and 2.2 times that of WSOC from corn and wheat burning emissions and 1.7 and 1.6 times that of HULIS. Though the mass contribution of WISOC among BBOA could be smaller than WSOC, their contribution to light absorption cannot be neglected due to the higher MAE of water-insoluble BBOA. The solar energy absorbed by biomass burning-emitted WISOC relative to EC ( $25 \%)$ among the wavelength range of $300-700 \mathrm{~nm}$ was higher than that of WSOC $(10 \%)$ or HULIS $(4 \%)$. The light absorption of BBOA would be largely underestimated if only the water-soluble fractions are considered. Previous studies also reported a large proportion of WISOC absorption in BBOA and ambient aerosols (Cheng et al., 2016b, 2017; Park et al., 2018; Sengupta et al., 2018).

Figure 7 clearly shows the dependence of the BBOA absorption coefficient $\left(\mathrm{Abs}_{365}\right)$ on burning conditions. A higher $\mathrm{Abs}_{365}$ of biomass-burning-generated $\mathrm{BrC}$ was observed under less efficient burning conditions for both corn and wheat burning experiments. This is mainly due to the elevated 

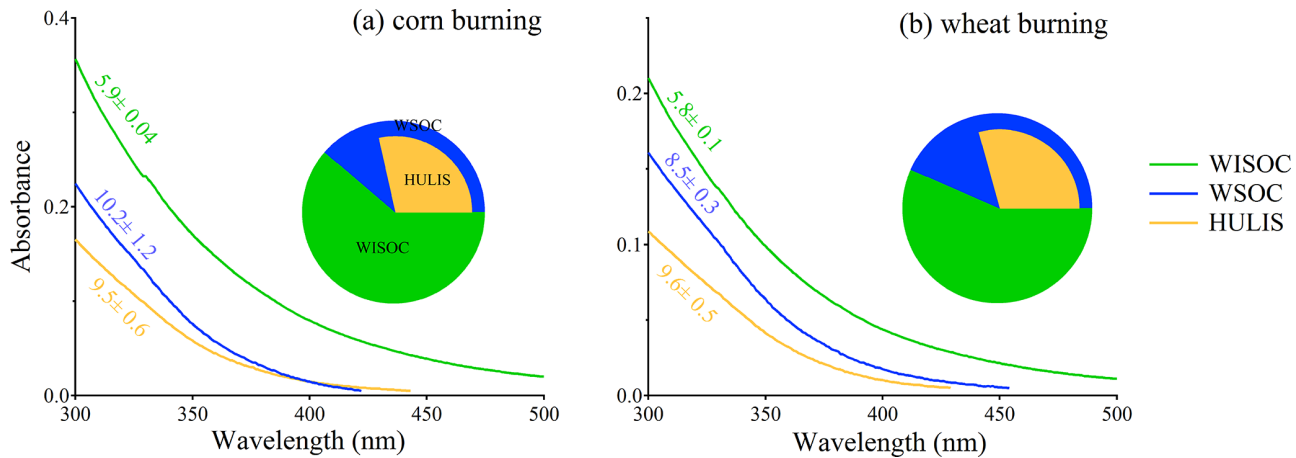

Figure 5. UV-Vis spectra of carbonaceous aerosol solutions, including WSOC, HULIS ${ }_{C}$ and WISOC, from (a) corn and (b) wheat burning experiments. The pie chart in each panel is the absorption contribution of different BBOA fractions at $300 \mathrm{~nm}$. The number represents the average AAE of each BBOA fraction derived from the absorption in the wavelength range of $300-450 \mathrm{~nm}$.

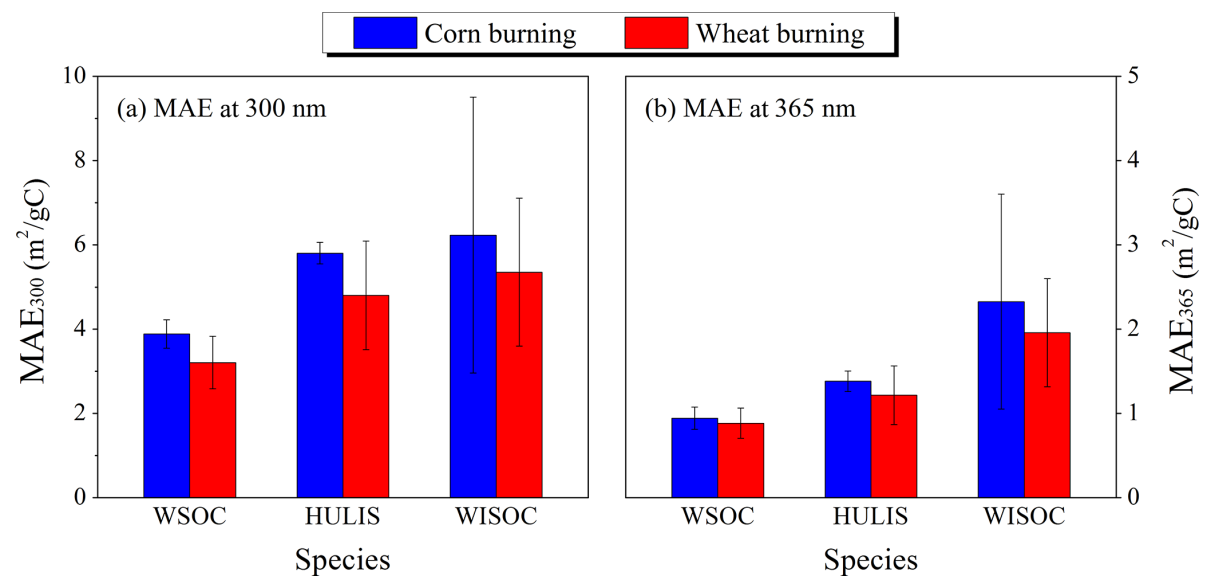

Figure 6. Mass absorption efficiency (MAE) of different organic carbonaceous aerosols, including WSOC, HULIS and WISOC emitted from corn and wheat burning.

BBOA emission factors as MCE decreases (Fig. 3). We did not observe obvious dependence of $\mathrm{MAE}_{365}$ on the combustion efficiency for either water-soluble fractions or WISOC (Fig. 7d-f). Previous lab and field studies suggested that the optical properties of biomass burning aerosols are more dependent on burning conditions other than fuel types (Liu et al., 2014; Xie et al., 2017). The MAE 365 of BBOA emitted from flaming combustion was reported to be higher than that from smoldering combustion based on lab-controlled burning experiments (Xie et al., 2019). Another lab experiment also suggested the dependence of $\mathrm{MAE}_{365}$ of methanolextracted BBOA on burning conditions, while the variation trends are different regarding different fuel types or sampling methods among different experiments (Xie et al., 2017). It is noted that a limited sample population was selected to conduct the light absorption measurements and that smoldering dominated the burning conditions in this study, which could be the reasons that we did not observe an obvious dependence of MAE on combustion conditions. More lab experiments, involving larger numbers of experiments and more variable burning conditions, are required to address the influence of combustion efficiency on the light absorption capability of biomass burning-emitted carbonaceous aerosols in future studies.

\section{Conclusions}

The emission factors of $\mathrm{PM}_{2.5}$, OC and EC were 9.3, 4.6 and $0.21 \mathrm{~g} \mathrm{~kg}^{-1}$ for corn burning and 8.7, 3.9 and $0.22 \mathrm{~g} \mathrm{~kg}^{-1}$ for wheat burning, generally lower than wood or forest burning emissions. Around $57 \%$ and $68 \%$ of the OC emitted from corn and wheat burning is WSOC, among which HULIS ${ }_{\mathrm{C}}$ represents $53 \%$ and $46 \%$ of the WSOC mass concentrations. Though the mass contribution of WISOC was lower than WSOC, the light absorption contribution of WISOC $(57 \%-84 \%$ at $300-400 \mathrm{~nm})$ surpassed WSOC due to the higher MAE of WISOC. The BBOA light absorption would be largely underestimated if only the water-soluble fractions were considered. Meanwhile, the light absorption of WSOC in the near-UV range, occupying $39 \%-43 \%$ of extracted 

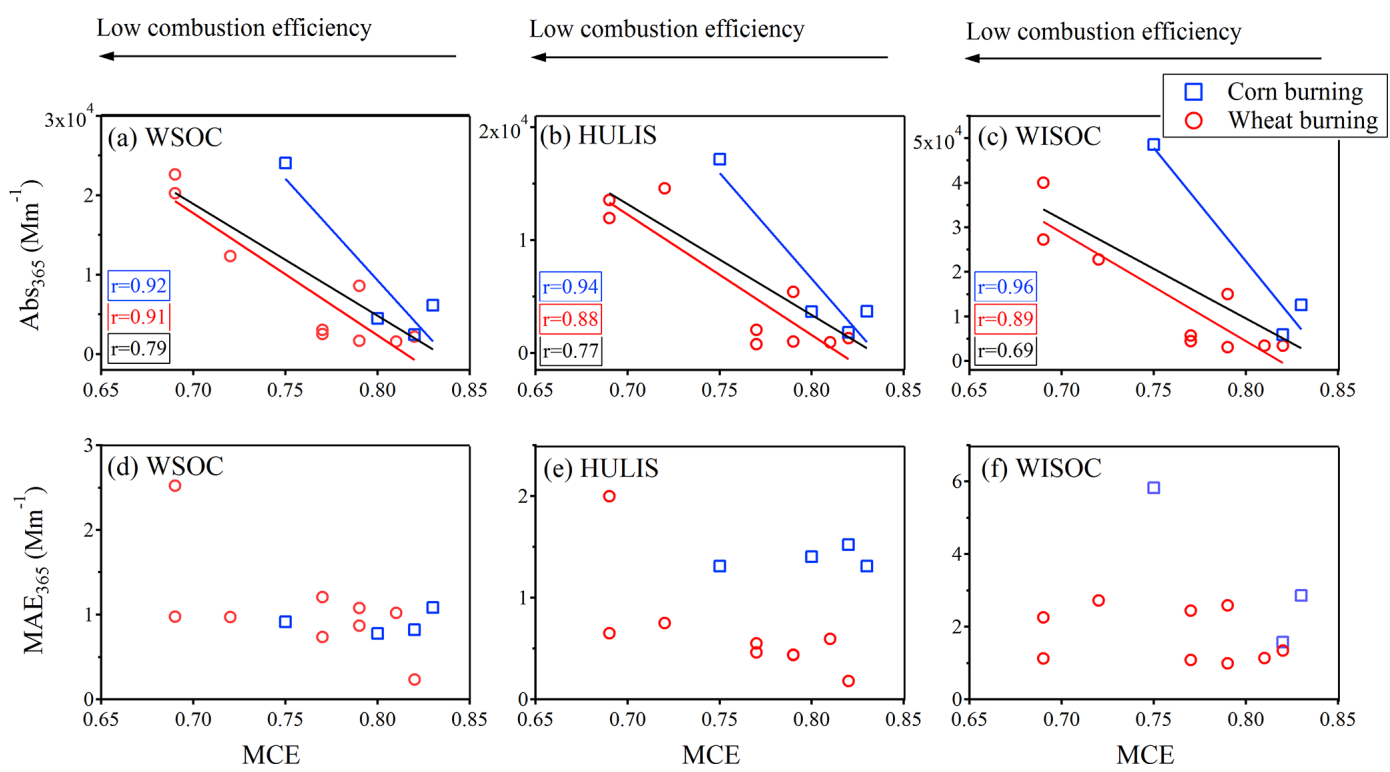

Figure 7. (a-c) Light absorption coefficients $\left(\mathrm{Abs}_{365}\right)$ and (d-f) mass absorption efficiency (MAE 365$)$ of WSOC, HULIS $\mathrm{C}$ and WISOC at $365 \mathrm{~nm}$ as a function of combustion efficiency. Corn and wheat burning emissions are denoted by red and blue colors, respectively. The $r$ values in (a)-(c) are the correlation coefficients for corn (blue), wheat (red) and overall (black) burning experiments.

OC absorption at $300 \mathrm{~nm}$, cannot be neglected due to their sharper increase of absorption towards shorter wavelengths compared with WISOC. HULIS were the major light absorption contributors to WSOC, and their light absorption capability was higher than other high-polarity WSOC components.

The emission levels, compositions and light absorption of BBOA were influenced by the burning conditions. The combustion conditions varied in different burning experiments, with the MCE ranging from 0.68 to 0.88 . The emission factors of $\mathrm{PM}_{2.5}$ and organic carbonaceous aerosols were obviously enhanced under less efficient burning conditions (lower MCE). The emission factors of $\mathrm{PM}_{2.5}$, OC, WSOC and HULIS $_{\mathrm{C}}$ from the most smoldering combustion experiment were about 3.4, 4.3, 3.8 and 2.8 times those from the most flaming combustion condition, regardless of the biofuel type employed in this study. The emission factors of $\mathrm{PM}_{2.5}$ and carbonaceous aerosols from high-moisture straw burning were obviously elevated compared with those from lowmoisture straw burning experiments. This is mainly due to the prolonged smoldering and incomplete combustion period during high-moisture biomass burning.

The $\mathrm{EC} /(\mathrm{EC}+\mathrm{OC})$ ratios showed a positive correlation with $\mathrm{MCE}$, though EC emission factors remain relative constant under different combustion conditions. Thus, it is reasonable to employ EC / OC or EC / (EC + OC) ratios as an indicator of biomass burning conditions. The mass ratios of WSOC / OC or HULIS $\mathrm{C}$ / OC did not display obvious variation trends under different combustion efficiency. However, the $\mathrm{K}^{+} / \mathrm{OC}$ and $\mathrm{Cl}^{-} / \mathrm{OC}$ ratios showed continuous increasing trends during higher efficiency burning, from $<0.1$ under the more smoldering condition to $>0.5$ under the more flaming condition for $\mathrm{K}^{+} / \mathrm{OC}$ and from 0.05 to $>0.5 \mathrm{for}^{-} / \mathrm{OC}$ ratios. This is mainly attributed to the elevated proportions of released potassium and chlorine from biofuels under the higher fire temperatures during flaming combustion. Our results indicate that the potassium ion, as a commonly used biomass burning tracer, may lead to large uncertainty in estimating biomass burning emission levels if the combustion conditions are not considered.

A higher absorption coefficient ( $\left.\mathrm{Abs}_{365}\right)$ of straw-burninggenerated $\mathrm{BrC}$, including WSOC, HULIS and WISOC, was observed under less efficient burning conditions for both corn and wheat burning. This is mainly attributed to the higher BBOA emission factors as MCE decreases. Our results suggested that the influence of varied combustion efficiency on the emission levels of BBOA could surpass the differences between biofuel types. Thus, the burning efficiency or combustion conditions should be taken into consideration when estimating the influence of biomass burning.

Data availability. The data presented in this article are available from the authors upon request (minhu@pku.edu.cn).

Supplement. The supplement related to this article is available online at: https://doi.org/10.5194/acp-20-13721-2020-supplement.

Author contributions. $\mathrm{MH}, \mathrm{ZW}, \mathrm{XH}$ and $\mathrm{LH}$ organized the project. YW conducted the simulation experiments. YW, NX and YQ analyzed the samples. YW wrote the manuscript with input from all co- 
authors. All authors contributed to discussing the results and commenting on the manuscript.

Competing interests. The authors declare that they have no conflict of interest.

Acknowledgements. We thank Song Guo for his helpful suggestions for this study.

Financial support. This research has been supported by the National Natural Science Foundation of China (grant nos. 91844301 and 91544214) and the China Postdoctoral Science Foundation (grant no. 2019M650354).

Review statement. This paper was edited by Kelley Barsanti and reviewed by two anonymous referees.

\section{References}

Akagi, S. K., Yokelson, R. J., Wiedinmyer, C., Alvarado, M. J., Reid, J. S., Karl, T., Crounse, J. D., and Wennberg, P. O.: Emission factors for open and domestic biomass burning for use in atmospheric models, Atmos. Chem. Phys., 11, 4039-4072, https://doi.org/10.5194/acp-11-4039-2011, 2011.

Andreae, M. O. and Gelencsér, A.: Black carbon or brown carbon? The nature of light-absorbing carbonaceous aerosols, Atmos. Chem. Phys., 6, 3131-3148, https://doi.org/10.5194/acp-63131-2006, 2006.

Andreae, M. O. and Merlet, P.: Emission of trace gases and aerosols from biomass burning, Global Biogeochem. Cy., 15, 955-966, https://doi.org/10.1029/2000gb001382, 2001.

Aurell, J. and Gullett, B. K.: Emission factors from aerial and ground measurements of field and laboratory forest burns in the southeastern US: $\mathrm{PM}_{2.5}$, black and brown carbon, VOC, and PCDD/PCDF, Environ. Sci. Technol., 47, 8443-8452, https://doi.org/10.1021/es402101k, 2013.

Bond, T. C.: A technology-based global inventory of black and organic carbon emissions from combustion, J. Geophys. Res., 109, D14203, https://doi.org/10.1029/2003jd003697, 2004.

Bond, T. C., Doherty, S. J., Fahey, D. W., Forster, P. M., Berntsen, T., DeAngelo, B. J., Flanner, M. G., Ghan, S., Kärcher, B., Koch, D., Kinne, S., Kondo, Y., Quinn, P. K., Sarofim, M. C., Schultz, M. G., Schulz, M., Venkataraman, C., Zhang, H., Zhang, S., Bellouin, N., Guttikunda, S. K., Hopke, P. K., Jacobson, M. Z., Kaiser, J. W., Klimont, Z., Lohmann, U., Schwarz, J. P., Shindell, D., Storelvmo, T., Warren, S. G., and Zender, C. S.: Bounding the role of black carbon in the climate system: A scientific assessment, J. Geophys. Res.-Atmos., 118, 5380-5552, https://doi.org/10.1002/jgrd.50171, 2013.

Chakrabarty, R. K., Moosmüller, H., Chen, L.-W. A., Lewis, K., Arnott, W. P., Mazzoleni, C., Dubey, M. K., Wold, C. E., Hao, W. M., and Kreidenweis, S. M.: Brown carbon in tar balls from smoldering biomass combustion, Atmos. Chem. Phys., 10, 6363 6370, https://doi.org/10.5194/acp-10-6363-2010, 2010.

Chen, J., Li, C., Ristovski, Z., Milic, A., Gu, Y., Islam, M. S., Wang, S., Hao, J., Zhang, H., He, C., Guo, H., Fu, H., Miljevic, B., Morawska, L., Thai, P., Lam, Y. F., Pereira, G., Ding, A., Huang, X., and Dumka, U. C.: A review of biomass burning: Emissions and impacts on air quality, health and climate in China, Sci. Total Environ., 579, 1000-1034, https://doi.org/10.1016/j.scitotenv.2016.11.025, 2017a.

Chen, L.-W. A., Verburg, P., Shackelford, A., Zhu, D., Susfalk, R., Chow, J. C., and Watson, J. G.: Moisture effects on carbon and nitrogen emission from burning of wildland biomass, Atmos. Chem. Phys., 10, 6617-6625, https://doi.org/10.5194/acp10-6617-2010, 2010.

Chen, Q., Ikemori, F., Higo, H., Asakawa, D., and Mochida, M.: Chemical Structural Characteristics of HULIS and Other Fractionated Organic Matter in Urban Aerosols: Results from Mass Spectral and FT-IR Analysis, Environ. Sci. Technol., 50, 17211730, https://doi.org/10.1021/acs.est.5b05277, 2016a.

Chen, Q., Ikemori, F., and Mochida, M.: Light Absorption and Excitation-Emission Fluorescence of Urban Organic Aerosol Components and Their Relationship to Chemical Structure, Environ. Sci. Technol., 50, 10859-10868, https://doi.org/10.1021/acs.est.6b02541, 2016b.

Chen, Q., Ikemori, F., Nakamura, Y., Vodicka, P., Kawamura, K., and Mochida, M.: Structural and Light-Absorption Characteristics of Complex Water-Insoluble Organic Mixtures in Urban Submicrometer Aerosols, Environ. Sci. Technol., 51, 82938303, https://doi.org/10.1021/acs.est.7b01630, 2017 b.

Chen, Y. and Bond, T. C.: Light absorption by organic carbon from wood combustion, Atmos. Chem. Phys., 10, 1773-1787, https://doi.org/10.5194/acp-10-1773-2010, 2010.

Cheng, Y., He, K.-B., Zheng, M., Duan, F.-K., Du, Z.-Y., Ma, Y.-L., Tan, J.-H., Yang, F.-M., Liu, J.-M., Zhang, X.-L., Weber, R. J., Bergin, M. H., and Russell, A. G.: Mass absorption efficiency of elemental carbon and water-soluble organic carbon in Beijing, China, Atmos. Chem. Phys., 11, 11497-11510, https://doi.org/10.5194/acp-11-11497-2011, 2011.

Cheng, Y., Engling, G., He, K.-B., Duan, F.-K., Ma, Y.-L., Du, Z.Y., Liu, J.-M., Zheng, M., and Weber, R. J.: Biomass burning contribution to Beijing aerosol, Atmos. Chem. Phys., 13, 77657781, https://doi.org/10.5194/acp-13-7765-2013, 2013.

Cheng, Y., Engling, G., Moosmüller, H., Arnott, W. P., Chen, L. W. A., Wold, C. E., Hao, W. M., and He, K.-B.: Light absorption by biomass burning source emissions, Atmos. Environ., 127, 347354, https://doi.org/10.1016/j.atmosenv.2015.12.045, $2016 \mathrm{a}$.

Cheng, Y., He, K.-B., Du, Z.-Y., Engling, G., Liu, J.-M., Ma, Y.-L., Zheng, M., and Weber, R. J.: The characteristics of brown carbon aerosol during winter in Beijing, Atmos. Environ., 127, 355-364, https://doi.org/10.1016/j.atmosenv.2015.12.035, $2016 \mathrm{~b}$.

Cheng, Y., He, K. B., Engling, G., Weber, R., Liu, J. M., Du, Z. Y., and Dong, S. P.: Brown and black carbon in Beijing aerosol: Implications for the effects of brown coating on light absorption by black carbon, Sci. Total Environ., 599-600, 1047-1055, https://doi.org/10.1016/j.scitotenv.2017.05.061, 2017.

Collier, S., Zhou, S., Onasch, T. B., Jaffe, D. A., Kleinman, L., Sedlacek III, A. J., Briggs, N. L., Hee, J., Fortner, E., Shilling, J. E., Worsnop, D., Yokelson, R. J., Parworth, C., Ge, X., Xu, J., Butterfield, Z., Chand, D., Dubey, M. K., Pekour, M. S., Springston, 
S., and Zhang, Q.: Regional Influence of Aerosol Emissions from Wildfires Driven by Combustion Efficiency: Insights from the BBOP Campaign, Environ. Sci. Technol., 50, 8613-8622, https://doi.org/10.1021/acs.est.6b01617, 2016.

Dhammapala, R., Claiborn, C., Corkill, J., and Gullett, B.: Particulate emissions from wheat and Kentucky bluegrass stubble burning in eastern Washington and northern Idaho, Atmos. Environ., 40, 1007-1015, https://doi.org/10.1016/j.atmosenv.2005.11.018, 2006.

Falkovich, A. H., Graber, E. R., Schkolnik, G., Rudich, Y., Maenhaut, W., and Artaxo, P.: Low molecular weight organic acids in aerosol particles from Rondônia, Brazil, during the biomassburning, transition and wet periods, Atmos. Chem. Phys., 5, 781797, https://doi.org/10.5194/acp-5-781-2005, 2005.

Fan, X., Li, M., Cao, T., Cheng, C., Li, F., Xie, Y., Wei, S., Song, J., and Peng, P. A.: Optical properties and oxidative potential of water- and alkaline-soluble brown carbon in smoke particles emitted from laboratory simulated biomass burning, Atmos. Environ., 194, 48-57, https://doi.org/10.1016/j.atmosenv.2018.09.025, 2018.

Feng, Y., Ramanathan, V., and Kotamarthi, V. R.: Brown carbon: a significant atmospheric absorber of solar radiation?, Atmos. Chem. Phys., 13, 8607-8621, https://doi.org/10.5194/acp13-8607-2013, 2013.

Guo, S., Hu, M., Wang, Z. B., Slanina, J., and Zhao, Y. L.: Sizeresolved aerosol water-soluble ionic compositions in the summer of Beijing: implication of regional secondary formation, Atmos. Chem. Phys., 10, 947-959, https://doi.org/10.5194/acp-10-9472010, 2010.

Hays, M. D., Fine, P. M., Geron, C. D., Kleeman, M. J., and Gullett, B. K.: Open burning of agricultural biomass: Physical and chemical properties of particle-phase emissions, Atmos. Environ., 39, 6747-6764, https://doi.org/10.1016/j.atmosenv.2005.07.072, 2005.

He, L.-Y., Lin, Y., Huang, X.-F., Guo, S., Xue, L., Su, Q., Hu, M., Luan, S.-J., and Zhang, Y.-H.: Characterization of highresolution aerosol mass spectra of primary organic aerosol emissions from Chinese cooking and biomass burning, Atmos. Chem. Phys., 10, 11535-11543, https://doi.org/10.5194/acp-10-115352010, 2010.

Hecobian, A., Zhang, X., Zheng, M., Frank, N., Edgerton, E. S., and Weber, R. J.: Water-Soluble Organic Aerosol material and the light-absorption characteristics of aqueous extracts measured over the Southeastern United States, Atmos. Chem. Phys., 10, 5965-5977, https://doi.org/10.5194/acp-10-5965-2010, 2010.

Hoffer, A., Gelencsér, A., Guyon, P., Kiss, G., Schmid, O., Frank, G. P., Artaxo, P., and Andreae, M. O.: Optical properties of humiclike substances (HULIS) in biomass-burning aerosols, Atmos. Chem. Phys., 6, 3563-3570, https://doi.org/10.5194/acp-6-35632006, 2006.

Holder, A. L., Hagler, G. S. W., Aurell, J., Hays, M. D., and Gullett, B. K.: Particulate matter and black carbon optical properties and emission factors from prescribed fires in the southeastern United States, J. Geophys. Res.-Atmos., 121, 3465-3483, https://doi.org/10.1002/2015jd024321, 2016.

Hungershoefer, K., Zeromskiene, K., Iinuma, Y., Helas, G., Trentmann, J., Trautmann, T., Parmar, R. S., Wiedensohler, A., Andreae, M. O., and Schmid, O.: Modelling the optical properties of fresh biomass burning aerosol produced in a smoke chamber: results from the EFEU campaign, Atmos. Chem. Phys., 8, 34273439, https://doi.org/10.5194/acp-8-3427-2008, 2008.

Jen, C. N., Hatch, L. E., Selimovic, V., Yokelson, R. J., Weber, R., Fernandez, A. E., Kreisberg, N. M., Barsanti, K. C., and Goldstein, A. H.: Speciated and total emission factors of particulate organics from burning western US wildland fuels and their dependence on combustion efficiency, Atmos. Chem. Phys., 19, 1013-1026, https://doi.org/10.5194/acp-19-1013-2019, 2019.

Jensen, P. A., Frandsen, F. J., Dam-Johansen, K., and Sander, B.: Experimental Investigation of the Transformation and Release to Gas Phase of Potassium and Chlorine during Straw Pyrolysis, Energ. Fuel, 14, 1280-1285, https://doi.org/10.1021/ef000104v, 2000.

Khan, A. A., de Jong, W., Jansens, P. J., and Spliethoff, H.: Biomass combustion in fluidized bed boilers: Potential problems and remedies, Fuel Process. Technol., 90, 21-50, https://doi.org/10.1016/j.fuproc.2008.07.012, 2009.

Kirillova, E. N., Andersson, A., Tiwari, S., Srivastava, A. K., Bisht, D. S., and Gustafsson, Ö.: Water-soluble organic carbon aerosols during a full New Delhi winter: Isotope-based source apportionment and optical properties, J. Geophys. Res.-Atmos., 119, 3476-3485, https://doi.org/10.1002/2013jd020041, 2014.

Knudsen, J. N., Jensen, P. A., and Dam-Johansen, K.: Transformation and release to the gas phase of $\mathrm{Cl}, \mathrm{K}$, and $\mathrm{S}$ during combustion of annual biomass, Energ. Fuel, 18, 1385-1399, https://doi.org/10.1021/ef049944q, 2004.

Laskin, A., Laskin, J., and Nizkorodov, S. A.: Chemistry of atmospheric brown carbon, Chem. Rev., 115, 4335-4382, https://doi.org/10.1021/cr5006167, 2015.

Levinson, R., Akbari, H., and Berdahl, P.: Measuring solar reflectance - Part I: Defining a metric that accurately predicts solar heat gain, Solar Energy, 84, 1717-1744, https://doi.org/10.1016/j.solener.2010.04.018, 2010.

Li, J. F., Song, Y., Mao, Y., Mao, Z. C., Wu, Y. S., Li, M. M., Huang, X., He, Q. C., and Hu, M.: Chemical characteristics and source apportionment of $\mathrm{PM}_{2.5}$ during the harvest season in eastern China's agricultural regions, Atmos. Environ., 92, 442-448, https://doi.org/10.1016/j.atmosenv.2014.04.058, 2014.

Li, M., Fan, X., Zhu, M., Zou, C., Song, J., Wei, S., Jia, W., and Peng, P.: Abundances and light absorption properties of brown carbon emitted from residential coal combustion in China, Environ. Sci. Technol., 53, 595-603, https://doi.org/10.1021/acs.est.8b05630, 2018.

Li, X., Wang, S., Duan, L., Hao, J., Li, C., Chen, Y., and Yang, L.: Particulate and trace gas emissions from open burning of wheat straw and corn stover in China, Environ. Sci. Technol., 41, 60526058, https://doi.org/10.1021/es0705137, 2007.

Lin, P. and Yu, J. Z.: Generation of reactive oxygen species mediated by humic-like substances in atmospheric aerosols, Environ. Sci. Technol., 45, 10362-10368, https://doi.org/10.1021/es2028229, 2011.

Lin, P., Engling, G., and Yu, J. Z.: Humic-like substances in fresh emissions of rice straw burning and in ambient aerosols in the Pearl River Delta Region, China, Atmos. Chem. Phys., 10, 64876500, https://doi.org/10.5194/acp-10-6487-2010, 2010.

Lin, P., Aiona, P. K., Li, Y., Shiraiwa, M., Laskin, J., Nizkorodov, S. A., and Laskin, A.: Molecular characterization of brown carbon in biomass burning aerosol particles, Environ. Sci. Technol., 50, 11815-11824, https://doi.org/10.1021/acs.est.6b03024, 2016. 
Liu, J., Bergin, M., Guo, H., King, L., Kotra, N., Edgerton, E., and Weber, R. J.: Size-resolved measurements of brown carbon in water and methanol extracts and estimates of their contribution to ambient fine-particle light absorption, Atmos. Chem. Phys., 13, 12389-12404, https://doi.org/10.5194/acp-13-123892013, 2013.

Liu, S., Aiken, A. C., Arata, C., Dubey, M. K., Stockwell, C. E., Yokelson, R. J., Stone, E. A., Jayarathne, T., Robinson, A. L., DeMott, P. J., and Kreidenweis, S. M.: Aerosol single scattering albedo dependence on biomass combustion efficiency: Laboratory and field studies, Geophys. Res. Lett., 41, 742-748, https://doi.org/10.1002/2013g1058392, 2014

Lu, H., Zhu, L., and Zhu, N.: Polycyclic aromatic hydrocarbon emission from straw burning and the influence of combustion parameters, Atmos. Environ., 43, 978-983, https://doi.org/10.1016/j.atmosenv.2008.10.022, 2009.

Park, S., Yu, G.-H., and Lee, S.: Optical absorption characteristics of brown carbon aerosols during the KORUSAQ campaign at an urban site, Atmos. Res., 203, 16-27, https://doi.org/10.1016/j.atmosres.2017.12.002, 2018.

Pathak, S., Jain, N., and Bhatia, A.: Crop Residues Management with Conservation Agriculture: Potential, Constraints and Policy Needs, edited by: Institute, I. A. R., India, 2012.

Pokhrel, R. P., Wagner, N. L., Langridge, J. M., Lack, D. A., Jayarathne, T., Stone, E. A., Stockwell, C. E., Yokelson, R. J., and Murphy, S. M.: Parameterization of single-scattering albedo (SSA) and absorption Ångström exponent (AAE) with EC / OC for aerosol emissions from biomass burning, Atmos. Chem. Phys., 16, 9549-9561, https://doi.org/10.5194/acp16-9549-2016, 2016.

Reid, J. S., Eck, T. F., Christopher, S. A., Koppmann, R., Dubovik, O., Eleuterio, D. P., Holben, B. N., Reid, E. A., and Zhang, J.: A review of biomass burning emissions part III: intensive optical properties of biomass burning particles, Atmos. Chem. Phys., 5, 827-849, https://doi.org/10.5194/acp-5-827-2005, 2005.

Reisen, F., Meyer, C. P., Weston, C. J., and Volkova, L.: Ground-Based Field Measurements of $\mathrm{PM}_{2.5}$ Emission Factors From Flaming and Smoldering Combustion in Eucalypt Forests, J. Geophys. Res.-Atmos., 123, 8301-8314, https://doi.org/10.1029/2018jd028488, 2018.

Saleh, R., Robinson, E. S., Tkacik, D. S., Ahern, A. T., Liu, S., Aiken, A. C., Sullivan, R. C., Presto, A. A., Dubey, M. K., Yokelson, R. J., Donahue, N. M., and Robinson, A. L.: Brownness of organics in aerosols from biomass burning linked to their black carbon content, Nature Geosci., 7, 647-650, https://doi.org/10.1038/ngeo2220, 2014.

Saleh, R., Marks, M., Heo, J., Adams, P. J., Donahue, N. M., and Robinson, A. L.: Contribution of brown carbon and lensing to the direct radiative effect of carbonaceous aerosols from biomass and biofuel burning emissions, J. Geophys. Res.-Atmos., 120, 10285-10296, https://doi.org/10.1002/2015jd023697, 2015.

Sanchis, E., Ferrer, M., Calvet, S., Coscollà, C., Yusà, V., and Cambra-López, M.: Gaseous and particulate emission profiles during controlled rice straw burning, Atmos. Environ., 98, 2531, https://doi.org/10.1016/j.atmosenv.2014.07.062, 2014.

Sengupta, D., Samburova, V., Bhattarai, C., Kirillova, E., Mazzoleni, L., Iaukea-Lum, M., Watts, A., Moosmüller, H., and Khlystov, A.: Light absorption by polar and non-polar aerosol compounds from laboratory biomass combustion, Atmos. Chem.
Phys., 18, 10849-10867, https://doi.org/10.5194/acp-18-108492018, 2018.

Streets, D. G., Yarber, K. F., Woo, J. H., and Carmichael, G. R.: Biomass burning in Asia: Annual and seasonal estimates and atmospheric emissions, Global Biogeochem. Cy., 17, 1099, https://doi.org/10.1029/2003gb002040, 2003.

Venkataraman, C., Habib, G., Kadamba, D., Shrivastava, M., Leon, J. F., Crouzille, B., Boucher, O., and Streets, D. G.: Emissions from open biomass burning in India: Integrating the inventory approach with high-resolution Moderate Resolution Imaging Spectroradiometer (MODIS) active-fire and land cover data, Global Biogeochem. Cy., 20, GB2013, https://doi.org/10.1029/2005gb002547, 2006.

Wang, Q., Itoh, S., Itoh, K., Apaer, P., Chen, Q., Niida, D., Mitsumura, N., Animesh, S., Sekiguchi, K., and Endo, T.: Behavior of suspended particulate matter emitted from combustion of agricultural residue biomass under different temperatures, Energ. Sustain., 176, 315-325, https://doi.org/10.2495/esus130271, 2013.

Wang, Y., Hu, M., Lin, P., Guo, Q., Wu, Z., Li, M., Zeng, L., Song, Y., Zeng, L., Wu, Y., Guo, S., Huang, X., and He, L.: Molecular characterization of nitrogen-containing organic compounds in humic-like substances emitted from straw residue burning, Environ. Sci. Technol., 51, 5951-5961, https://doi.org/10.1021/acs.est.7b00248, 2017.

Washenfelder, R. A., Attwood, A. R., Brock, C. A., Guo, H., Xu, L., Weber, R. J., Ng, N. L., Allen, H. M., Ayres, B. R., Baumann, K., Cohen, R. C., Draper, D. C., Duffey, K. C., Edgerton, E., Fry, J. L., Hu, W. W., Jimenez, J. L., Palm, B. B., Romer, P., Stone, E. A., Wooldridge, P. J., and Brown, S. S.: Biomass burning dominates brown carbon absorption in the rural southeastern United States, Geophys. Res. Lett., 42, 653-664, https://doi.org/10.1002/2014g1062444, 2015.

Wu, G., Wan, X., Gao, S., Fu, P., Yin, Y., Li, G., Zhang, G., Kang, S., Ram, K., and Cong, Z.: Humic-like substances (HULIS) in aerosols of central Tibetan Plateau (Nam Co, $4730 \mathrm{~m}$ asl): Abundance, light absorption properties, and sources, Environ. Sci. Technol., 52, 7203-7211, https://doi.org/10.1021/acs.est.8b01251, 2018.

Wu, G., Ram, K., Fu, P., Wang, W., Zhang, Y., Liu, X., Stone, E. A., Pradhan, B. B., Dangol, P. M., Panday, A. K., Wan, X., Bai, Z., Kang, S., Zhang, Q., and Cong, Z.: Water-soluble brown carbon in atmospheric aerosols from Godavari (Nepal), a regional representative of South Asia, Environ. Sci. Technol., 53, 3471-3479, https://doi.org/10.1021/acs.est.9b00596, 2019.

Wu, G., Wan, X., Ram, K., Li, P., Liu, B., Yin, Y., Fu, P., Loewen, M., Gao, S., Kang, S., Kawamura, K., Wang, Y., and Cong, Z.: Light absorption, fluorescence properties and sources of brown carbon aerosols in the Southeast Tibetan Plateau, Environ. Pollut., 257, 113616, https://doi.org/10.1016/j.envpol.2019.113616, 2020.

Xie, M., Hays, M. D., and Holder, A. L.: Light-absorbing organic carbon from prescribed and laboratory biomass burning and gasoline vehicle emissions, Sci. Rep., 7, 7318, https://doi.org/10.1038/s41598-017-06981-8, 2017.

Xie, M., Shen, G., Holder, A. L., Hays, M. D., and Jetter, J. J.: Light absorption of organic carbon emitted from burning wood, charcoal, and kerosene in household cookstoves, Environ. Pollut. 240, 60-67, https://doi.org/10.1016/j.envpol.2018.04.085, 2018. 
Xie, M., Chen, X., Hays, M. D., and Holder, A. L.: Composition and light absorption of $\mathrm{N}$-containing aromatic compounds in organic aerosols from laboratory biomass burning, Atmos. Chem. Phys., 19, 2899-2915, https://doi.org/10.5194/acp-192899-2019, 2019.

Yan, J., Wang, X., Gong, P., Wang, C., and Cong, Z.: Review of brown carbon aerosols: Recent progress and perspectives, Sci. Total Environ., 634, 1475-1485, https://doi.org/10.1016/j.scitotenv.2018.04.083, 2018.

Zanatta, E. R., Reinehr, T. O., Awadallak, J. A., Kleinübing, S. J., dos Santos, J. B. O., Bariccatti, R. A., Arroyo, P. A., and da Silva, E. A.: Kinetic studies of thermal decomposition of sugarcane bagasse and cassava bagasse, J. Therm. Anal. Calorim., 125, 437-445, https://doi.org/10.1007/s10973-016-5378-x, 2016.
Zhang, G., Li, J., Li, X. D., Xu, Y., Guo, L. L., Tang, J. H., Lee, C. S., Liu, X., and Chen, Y. J.: Impact of anthropogenic emissions and open biomass burning on regional carbonaceous aerosols in South China, Environ. Pollut., 158, 3392-3400, https://doi.org/10.1016/j.envpol.2010.07.036, 2010.

Zhang, X., Lin, Y. H., Surratt, J. D., and Weber, R. J.: Sources, composition and absorption Angstrom exponent of light-absorbing organic components in aerosol extracts from the Los Angeles Basin, Environ. Sci. Technol., 47, 3685-3693, https://doi.org/10.1021/es305047b, 2013.

Zhu, C. S., Cao, J. J., Huang, R. J., Shen, Z. X., Wang, Q. Y., and Zhang, N. N.: Light absorption properties of brown carbon over the southeastern Tibetan Plateau, Sci. Total Environ., 625, 246251, https://doi.org/10.1016/j.scitotenv.2017.12.183, 2018. 